This work is licensed under a Creative Commons Attribution 3.0 License.

\author{
Research article
}

\title{
New Antarctic stenothoids sensu lato (Amphipoda, Crustacea)
}

\author{
Traudl KRAPP-SCHICKEL \\ Forschungsmuseum A. Koenig, Adenauerallee 160, D-53113 Bonn, Germany \\ E-mail: traudl.krapp@uni-bonn.de
}

Krapp-Schickel T. 2011. New Antarctic stenothoids sensu lato (Amphipoda, Crustacea). European Journal of Taxonomy 2: 1-17. http://dx.doi.org/10.5852/ejt.2011.2

\begin{abstract}
Three stenothoid species are reported from recent Antarctic collections. Two of these are new to science (Prometopa cedrici sp. nov. and Antatelson claudei sp. nov.). A few character states of Antatelson walkeri are discussed. Keys are provided for Prometopa as well as for Antatelson.
\end{abstract}

Key words. Crustacea, Amphipoda, Stenothoidae, Antarctica, Southern Ocean.

\section{Introduction}

During a visit to the Royal Belgian Institute of Natural Sciences in Brussels, Cedric d'Udekem d'Acoz showed me some amphipod specimens from his Antarctic samples, partly collected by himself during the Polarstern-cruise, partly given to him by the British Antarctic Survey. They all have an unusual wedge-shaped body and probably live in the same habitat. Two of three species, collected together in one sample, turned out to be new to science.

\section{Material and Methods}

Complete specimens were studied in temporary glycerine slides, preparations made in Faure's fluid and both studied under a Wild M20 microscope. Pencil drawings were scanned in and 'inked' by applying the software Adobe Illustrator CS 3 and Wacom tablets A4 and A5, using the method described in Coleman $(2003,2009)$.

D'Udekem d'Acoz (2010: 129) revived the already long-lasting discussion about the terminology of setae, teeth and spines. There is no doubt that articulated structures on the cuticle are homologous, regardless whether thin or thick, but I agree that the expression 'robust seta' is a very unhelpful one, as setae in most biologists' language are associated with something slender and flexible. The border between 'seta' and 'robust seta' is just as impossible to objectify as the border between 'seta' and 'spine', there is a continuous transition. I therefore shall continue to use the terms seta and spine in the classical meaning and expect that since the paper of Watling (1989) the reader will anyway know that they are homologous. 
Much more confusing is the statement in Lowry \& Stoddart (1995: 8) that those non-articulated cuticular structures that previously always have been called 'teeth' would in future be called by these authors 'spines'. It is highly dangerous to use the existing and well-established term 'spine' in a completely different sense and results in a similar situation to that where some authors counted peraeopods 3-5, while others called the same structures P5-7: one is never quite sure what this particular author means in this particular paper. This idea was then applied and defended in the wonderful publication on the Great Barrier Reef, so that for example in the contribution by Krapp-Schickel (2009: 598-642) the word 'teeth' on the shape of epimeral plates, urosomites or pleon everywhere was replaced by the word 'spines' by the editors for the sake of homogeneity in the book. At school, small children in Central Europe learn about roses which can have thorns or spines, and the difference is stressed that spines are articulated and easily removable because they are produced by the 'skin', while thorns are created like branches and are quite difficult to remove. This definition is old, often used also in other literature and thus the word 'spine' in amphipod terminology should be kept unchanged to avoid confusion in understanding, meaning an articulated structure.

Besides the articulation there exists also a lively discussion about the shape. Some authors point out that 'teeth' in humans have different shapes, can be molars or incisors but rarely are distally pointed (whereas fish teeth are very often distally pointed, as are teeth of snakes). Biologists no doubt are aware that the teeth of crustaceans are not homologous with those of vertebrates (nor are all vertebrate teeth homologous, while our teeth are homologous to the scales of sharks; nor are our teeth homologous with the ones of a toothed leaf margin in a tree, or with the teeth of conodonts...). Nevertheless, the expression 'tooth' for a pointed non-articulated structure is commonly used in many different organisms, often also as the adjective 'toothed', and in this more general usage it does not imply homologous structures.

In this paper the following terms are applied in the same way as in most of my earlier publications:

tooth $=$ non-articulated pointed ectodermal structure

spine $=$ stout, articulated structure (synonymous to 'robust seta')

seta $=$ slender, flexible articulated structure.

\section{Abbreviations}

$\begin{array}{lll}\text { A1, A2 } & = & \text { antenna 1,2 } \\ \text { acc. } & = & \text { accessory } \\ \text { art. } & = & \text { article } \\ \text { Cx1-7 } & = & \text { coxa 1-7 } \\ \text { Ep1-3 } & = & \text { epimera or epimeral plates } \\ \text { flag } & = & \text { flagellum } \\ \text { Gn1, Gn2 } & = & \text { gnathopod 1, } 2 \\ \mathrm{IP} & = & \text { inner plate } \\ \text { Md } & = & \text { mandible } \\ \text { Mx1, Mx2 } & = & \text { maxilla 1, } \\ \text { OP } & = & \text { outer plate } \\ \text { P3-7 } & = & \text { peraeopod 3-7 } \\ \text { P11-P13 } & = & \text { pleonite 1-3 } \\ \text { Pn } & = & \text { peraeonite } \\ \text { T } & = & \text { telson } \\ \text { U1-U3 } & = & \text { uropod 1-3 } \\ \text { Us1-Us3 } & = & \text { urosomites 1-3 }\end{array}$




\title{
Systematics
}

\author{
Family Stenothoidae \\ Genus Prometopa Schellenberg, 1926
}

Type species: P. tuberculata Schellenberg, 1926

There are currently three included species: P. dorsoundata Bushueva, 1988; P. edentata Rauschert, 1990; P tuberculata Schellenberg, 1926.

\section{Diagnostic characters}

A1 with (P. edentata, P. tuberculata) or without (P. dorsoundata, P. cedrici) nasiform process on art. 1. Acc. flag. vestigial. Md palp with 3 arts. Mx1 palp with often not clearly visible articulation between first and second art. Mx2 IP ordinary. Mxp IP well separated. Gn1, 2 different from each other in size and shape, Gn1 small, propodus and carpus long and narrow; Gn2 enlarged, palm oblique, carpus short, lobed. P5 with basis rectolinear, P6, 7 basis rounded. Peraeonites dorsally elevated, peraeonite 4 slightly elongated. Pleonites 2, 3 with dorsal process, pleonites 4-6 free. Telson ordinary, flat.

\section{Prometopa cedrici sp. nov.}

Figs 1-6

\section{Holotype}

đ? $4.5 \mathrm{~mm}$, fully dissected and mounted in slides in Faure's liquid; RBINS, I.G. 310712 slides: IG 31071 / INV 83816A and IG 31071 / INV 83816B (Museum Brussels). R/V Polarstern, cruise ANTARKTISXXIII/8, Larsen B area, station 702-9 B_South $65^{\circ} 57.85^{\prime} \mathrm{S} 60^{\circ} 28.42^{\prime} \mathrm{W}$ to $65^{\circ} 57.42^{\prime} \mathrm{S} 60^{\circ} 28.12^{\prime} \mathrm{W}$, 12/01/2007, 215-221 m, hard bottom with a lot of hydrocorals; gear: Agassiz trawl.

\section{Paratype}

+ , $4.8 \mathrm{~mm}$, partly dissected, dissected parts mounted on 2 slides, registration numbers: RBINS, IG 31071 / INV 83816B and INV 83816C (Museum Brussels), same locality as above.

\section{Etymology}

Dedicated to Cédric d'Udekem d'Acoz (Brussels), extremely careful taxonomist for amphipods and decapods.

\section{Description}

Habitus. Dorsal outline spiky from peraeonite 1-5, the next four body segments reinforced dorsally, appearing 'double folded', with rounded outline. Suture between urosomites not clear.

HEAD. A1 subequal to A2. A1 peduncle art. $1>$ art. 2, ratio art. 2:art. $3=2$; art. 1 ordinary, without nasiform process; flagellum with 14 arts. A 2 art. $4>$ art. 5, flagellum with $8-9$ arts.

Mouthparts: Md molar small; palp longer than Md body, ratio art. 2:art. 3 = about 3, sparse and regular setation on art. 2, only one distal seta on art. 3. Mx1 palp with 2 arts. Mx2 IP about half length of OP, both with long setae distally, next to them some short ones.

GNathopods. Gn1 much smaller than Gn2. Cx1 semicircularly rounded distally. Basis robust and distally widening, on anterior margin long and short setae, on posterior one only short setae. Ischium longer than wide, with long setae distally. Merus distoposteriorly lengthened and beset with short and stiff setae, also two long setae and two spines distally. Carpus triangular, beset with long setae on anterior and posterior margin. Propodus 3-4 times as long as wide, on all margins some long setae, palm weakly rounded without any palmar corner, but defined by 5 spines. 
Gn2 strong. Cx2 tongue-shaped, about twice as long as wide, with nearly parallel margins. Basis 3.5 times longer than wide, anterior margin densely beset with many fine setae, only 3 setae on posterior margin. Ischium somewhat longer than wide, like merus with few setae. Carpus triangular, shorter than wide, distally lobed with long distal and shorter marginal setae. Propodus subrectangular, distally a bit wider than proximally, with irregular setae anteriorly and posteriorly; palmar corner nearly rectangular, with prominent robust tooth, palm with U-shaped excavation medially and many small incisions. Dactylus short and strong, with many short setae on the inner side.

Peraeopods. P3 slender. Cx3 similar to $\mathrm{Cx} 2$, about 2.5 times as long as wide, with parallel margins. Basis and ischium about twice as wide as propodus and carpus, merus acutely lengthened anterodistally. Dactylus strong. P4 clearly stronger than P3: Cx4 subtrapezoidal, about as long as wide. Basis and

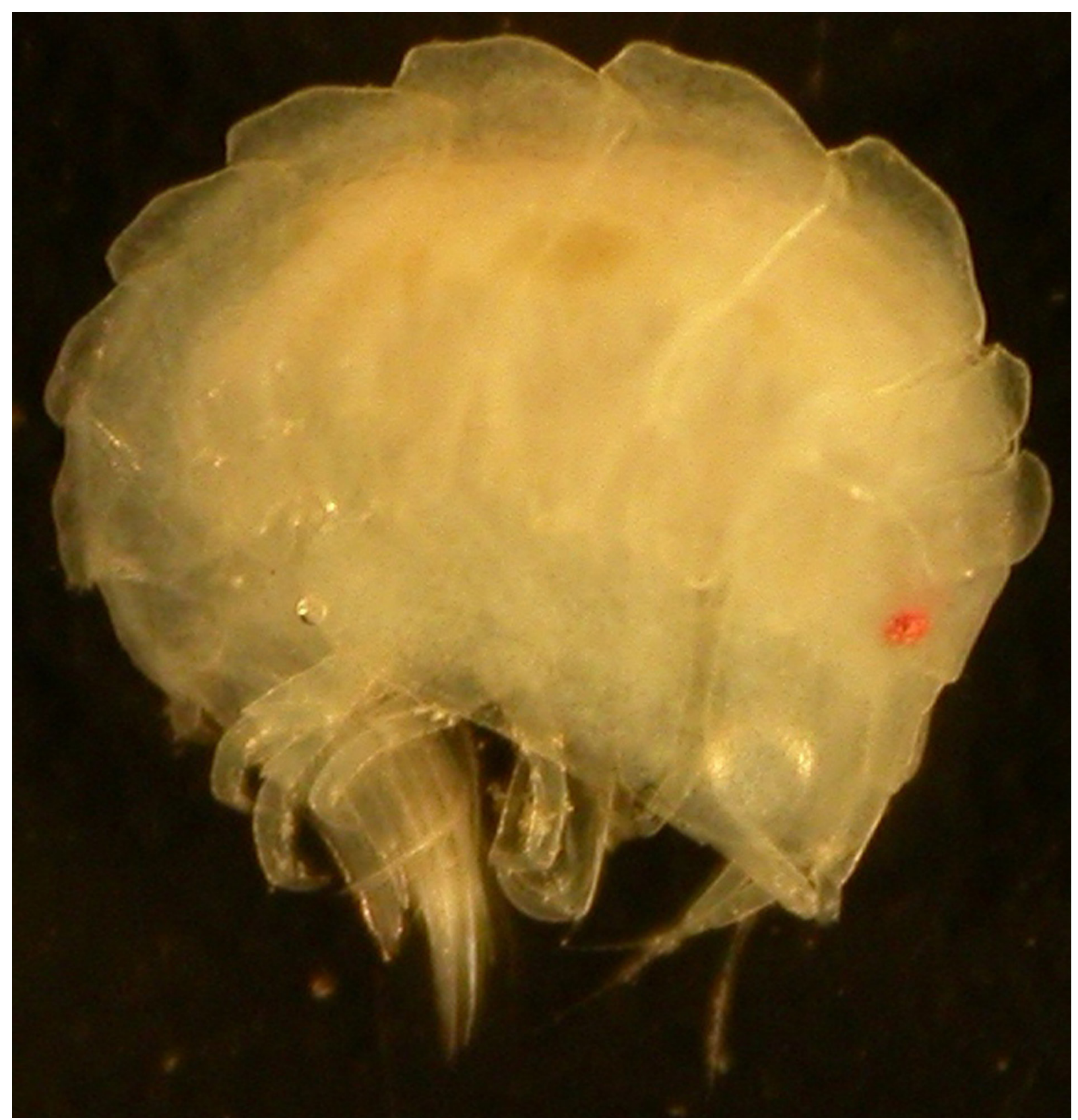

Fig. 1. Prometopa cedrici sp. nov. Paratype:,$+ 4.8 \mathrm{~mm}$. Photo by Cedric d'Udekem d'Acoz. 

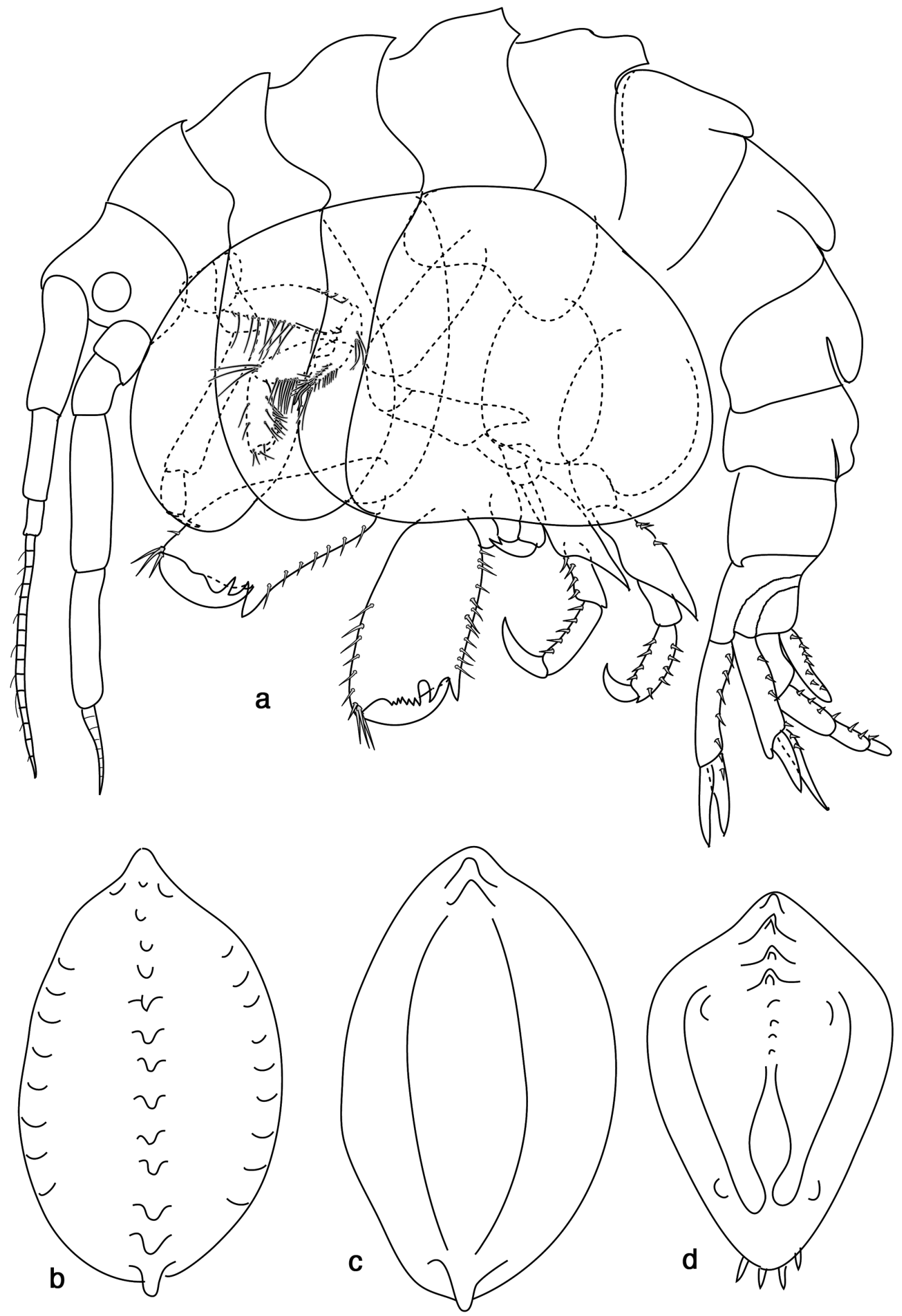

Fig. 2. Prometopa cedrici sp. nov. Paratype: $\uparrow, 4.8 \mathrm{~mm}$. Habitus a) laterally; b) dorsally; c) ventrally; d) frontally. 

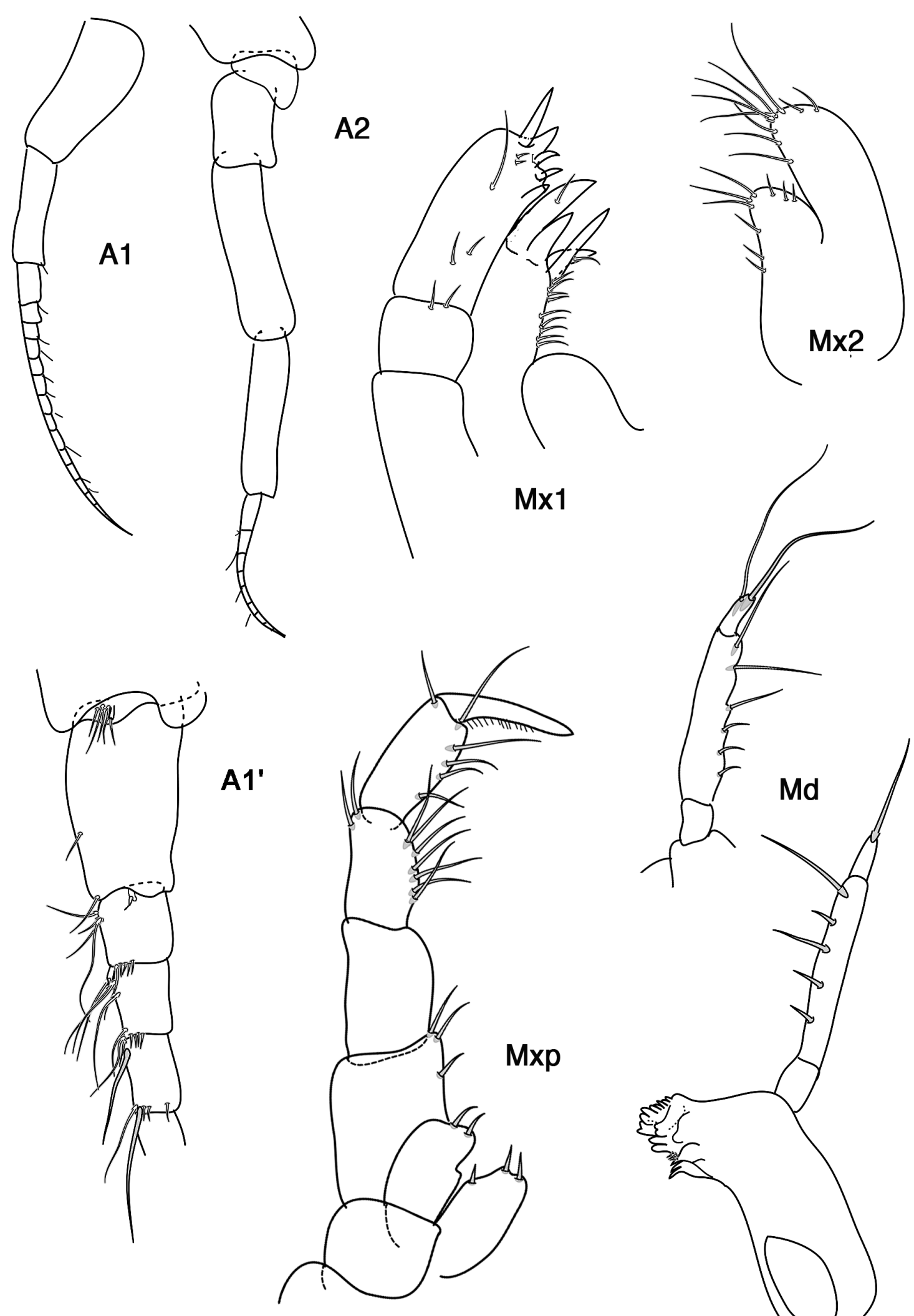


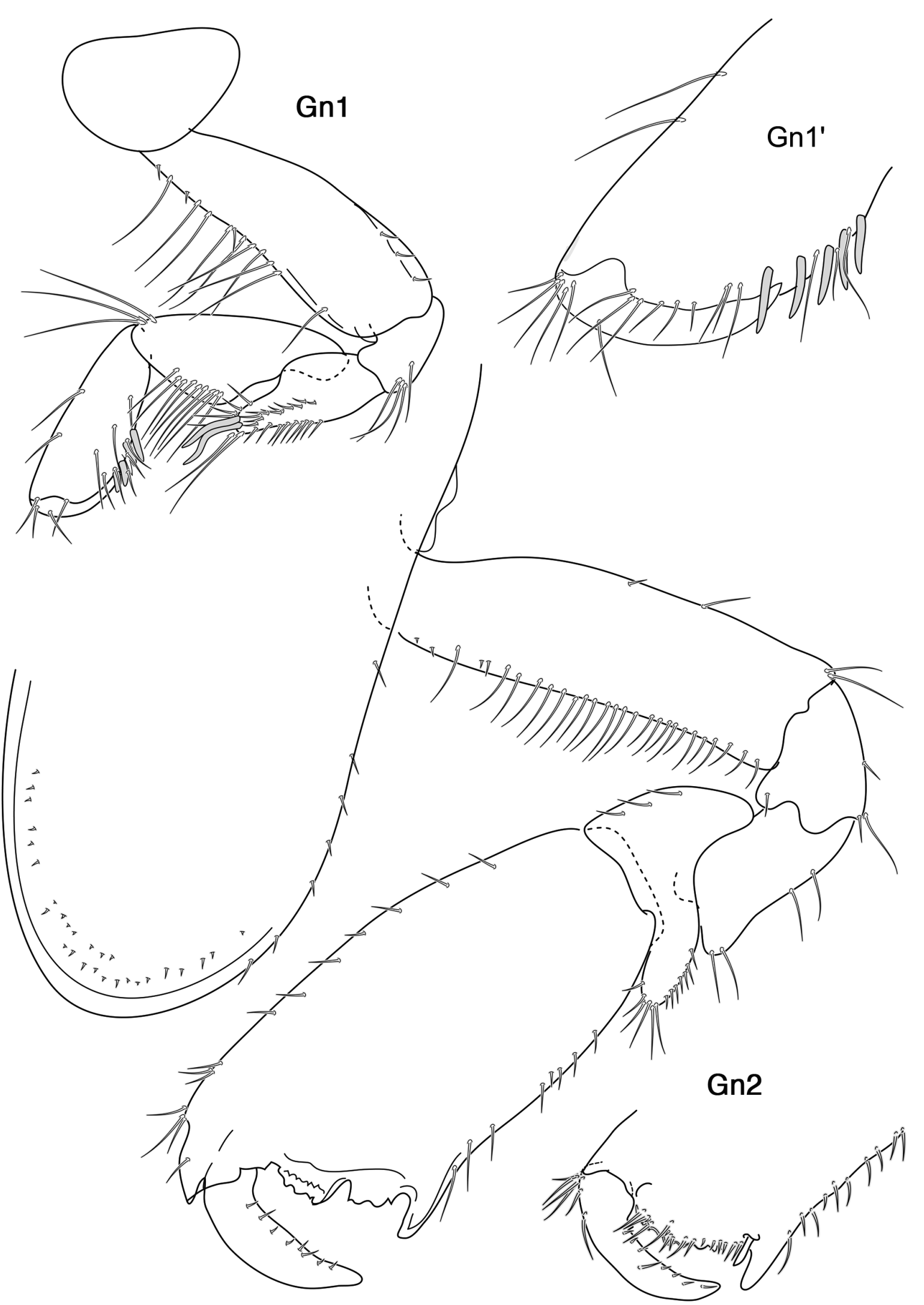

Fig. 4. Prometopa cedrici sp. nov. Paratype: + , $4.8 \mathrm{~mm}$. Gn1, 2 = gnathopods; Gn1' = propodus of first gnathopod enlarged. 


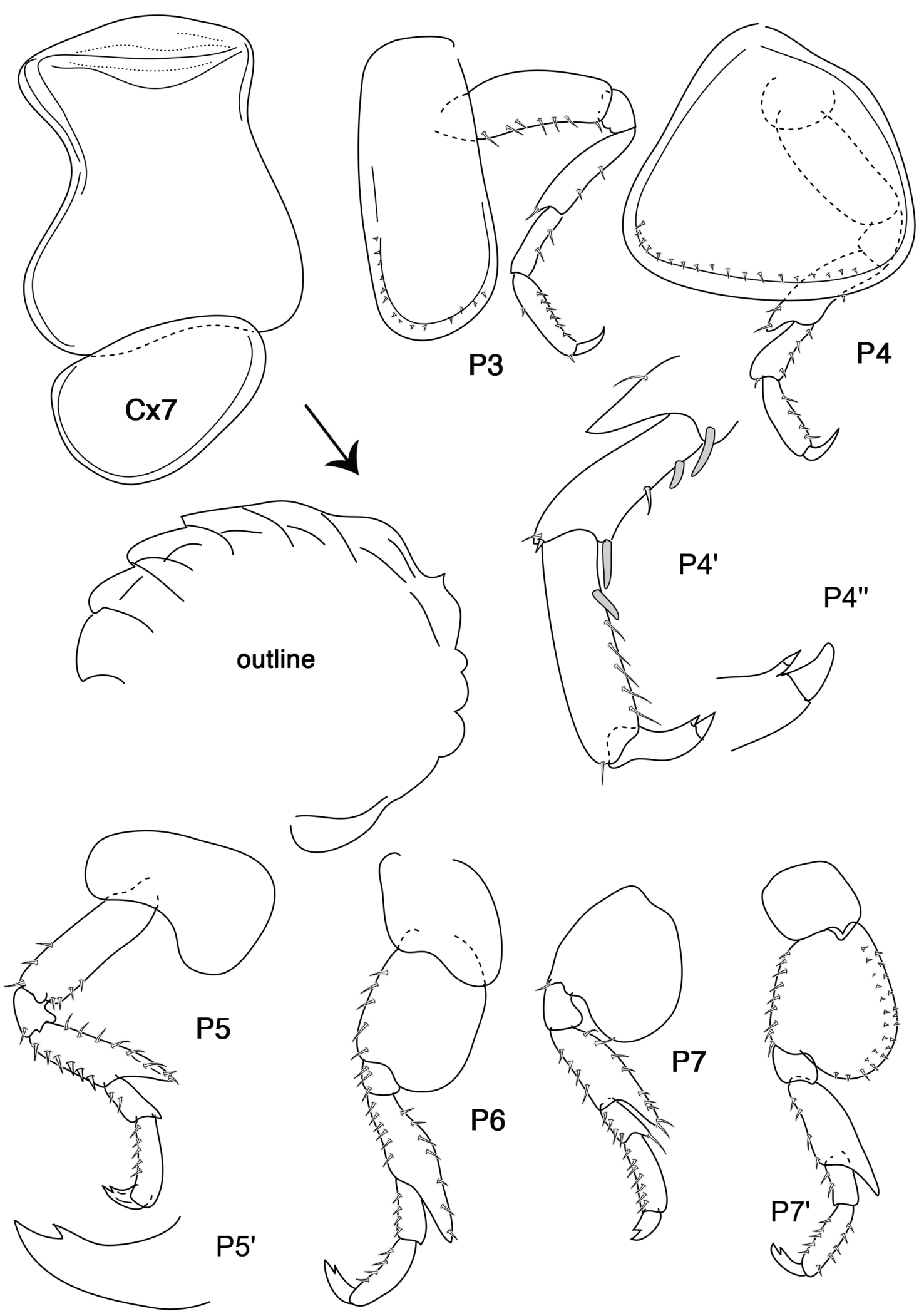

Fig. 5. Prometopa cedrici sp. nov. Paratype: $q, 4.8 \mathrm{~mm} . \mathrm{Cx} 7=$ coxa 7 with peraeonite 7 , showing the thickened dorsal part; outline: shape of middorsal bodyline (head on left side); P3-7 peraeopod 3-7; P4', P4" distal part of peraeopod 4 enlarged; P5' dactylus of P5 enlarged. 

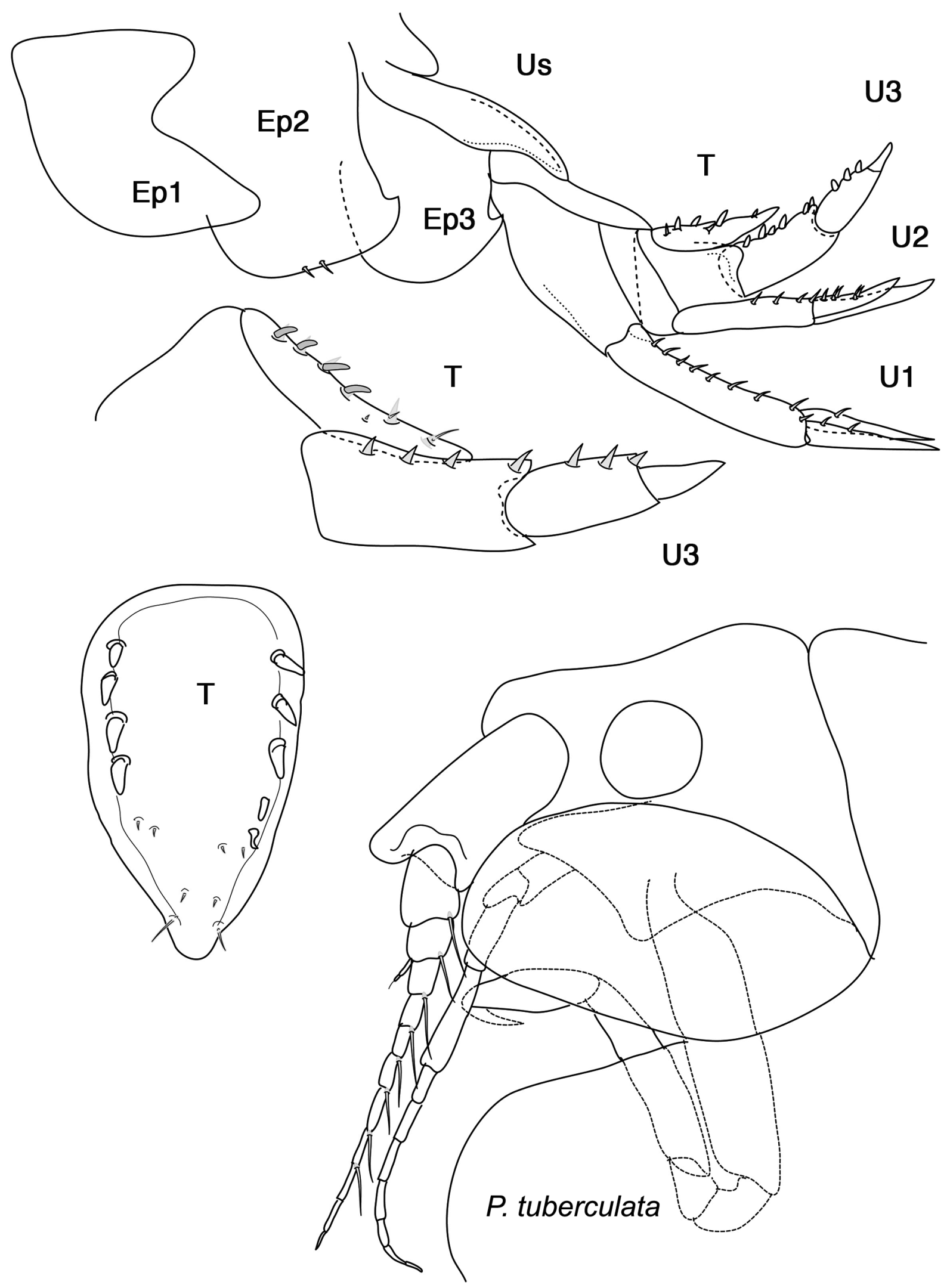

Fig. 6. Prometopa cedrici sp. nov. Paratype: + , $4.8 \mathrm{~mm}$. Ep1-3 = epimeral plates 1-3; Us = urosome with U1-3 = uropods 1-3; T = telson. Below right: Prometopa tuberculata head with Gn1. 
ischium similar to P3. Merus much wider than in P3, acutely lengthened anterodistally. Carpus distad widening, with short spines. Propodus with spines and setae. Dactylus distally bifid. P5 similar to P4, strong and richly beset with spines and setae on both margins; basis rectangular, merus posteriorly lengthened, reaching about half length of carpus; dactylus robust, bifid. P6 similar to P5 but basis widened, posterior margin straight, merus posteriorly reaching end of carpus. P7 similar to P6 but basis posteriorly much more widened, margin rounded.

Pleon. P11-3 and Us1 dorsally thickened, with 'double pleat'.

Ep1 tongue-shaped lengthened posterodistally. Ep2, 3 with small upturned tooth posterodistally.

Us2 much narrower than Us1 or Us3.

U1 peduncle much longer than subequal rami, with small spines. U2 peduncle longer than longer ramus, ratio of length of rami about 3:2; with small spines. U3 very strong, peduncle shorter than in U2, but about twice as wide, with strong spines; ramus two-articulated, articles about the same length and also with strong spines on first article.

TeLson. Triangular, flappable, about 1.7 times longer than wide, with 4-5 strong spines marginally.

\section{Remarks}

This genus seems quite closely related to the following one, in partly sharing also a nasiform thickened A1 peduncle and varying humps dorsally. But the telson is flappable and horizontally inserted, as in ordinary stenothoids, and the propodi of the gnathopods are very different in size and shape.

For comparing this new species with other members of the genus, see key:

\section{Key to Prometopa species}

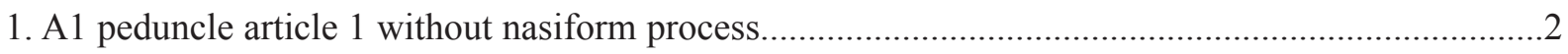

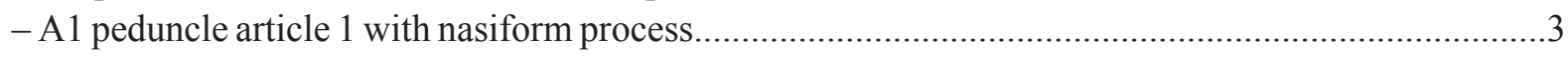

2. Gn2 palm smooth, oblique, not defined; $\mathrm{Cx} 4$ posteriorly excavated, $\mathrm{Cx} 5$ longer than broad; $\mathrm{T} 2$ pairs of spines; body segments dorsally smooth.

...Prometopa dorsoundata Bushueva, 1988

- Gn2 nearly rectipalmate, well defined by strong and prominent tooth; $\mathrm{Cx} 4$ posteriorly not excavated, Cx5 broader than long; T with 4-6 pairs of spines; posterior body segments dorsally 'pleated'. Prometopa cedrici sp. nov

3. Strong sexual dimorphism, head with lacking prolongation, two acute dorsal protuberances on pleon segments. Prometopa tuberculata Schellenberg, 1926

- Lacking sexual dimorphism, head with anterior prolongation, lacking dorsal protuberances on pleon segments Prometopa edentata Rauschert, 1990

Barnard \& Karaman (1991) called the stenothoid group with enlarged, thickened and vertically inserted telson 'subgroup thaumatelsonins'. In Krapp-Schickel (2006) as well as DeBroyer et al. (2007: 221) it is cited as 'subfamily Thaumatelsoninae' and Krapp-Schickel \& Koenemann (2006) used various cladistic analyses in an effort to separate all thaumatelsonid members from the other stenothoids.

There is no doubt that thaumatelsonids are different, but the more stenothoids we discover, the less justified it seems to formally divide the huge number of stenothoid genera into different families or subfamilies with clearcut synapomorphies (something which I aimed at for long time), as there are always some bridging species with shared character states. However, the term 'Thaumatelsonin stenothoids' remains useful keeping in mind that this group most probably is not a completely natural clade. 


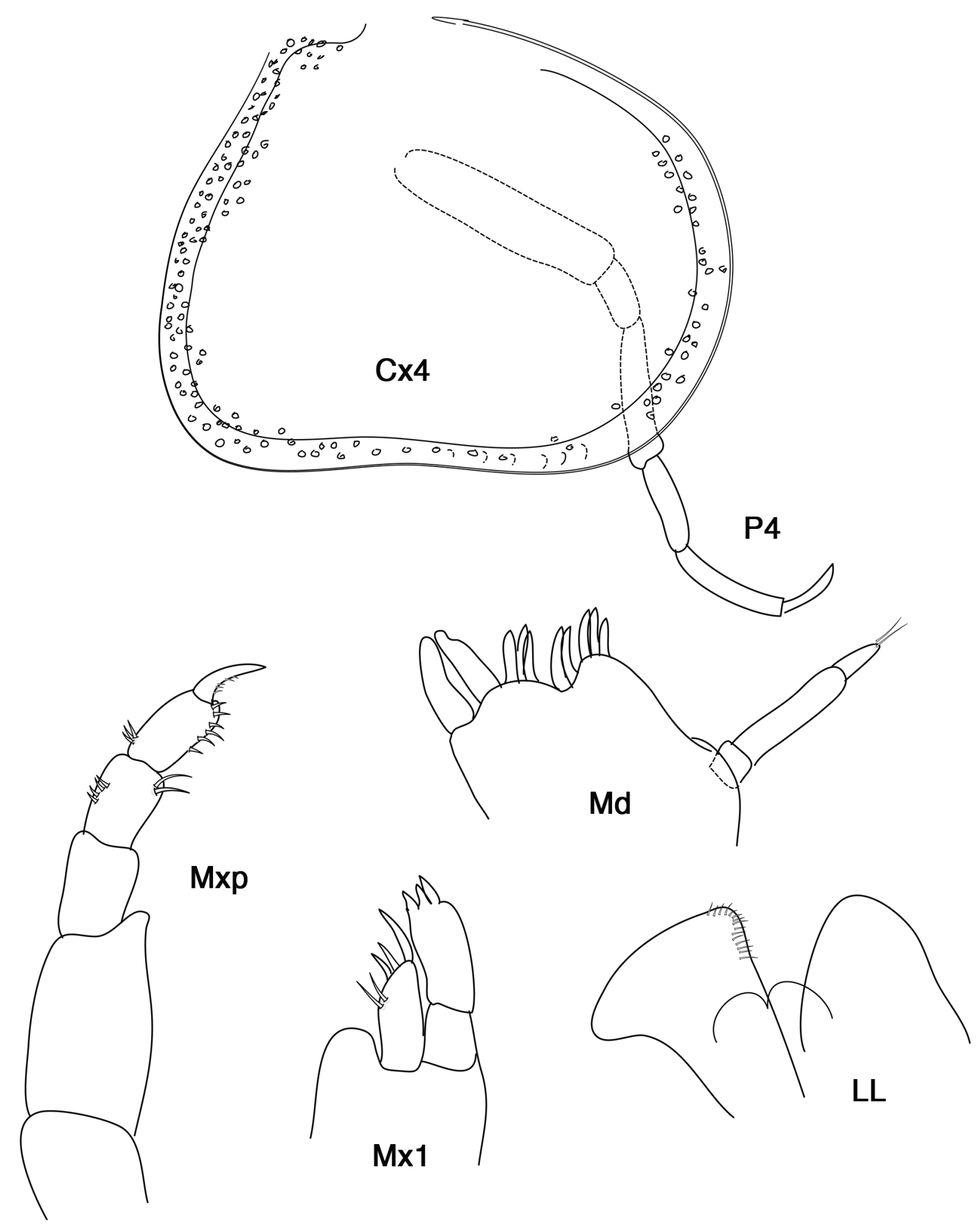

Fig. 7. Antatelson walkeri (Chilton, 1912). sex?, $2.5 \mathrm{~mm} . \mathrm{Cx} 4=\operatorname{coxa} 4$; $\mathrm{P} 4=$ peraeopod 4; Mxp = maxilliped; $\mathrm{Mx} 1=$ first maxilla; $\mathrm{Md}=$ mandible; $\mathrm{LL}=$ lower lip. 
Genus Antatelson J.L. Barnard, 1972

Type species: Thaumatelson walkeri Chilton, 1912

There are currently six included species: A. antennatum Bellan-Santini \& Ledoyer, 1974; A. cultricauda (K.H. Barnard, 1932), A. cuneatum Krapp-Schickel, 2006; A. rostratum Bellan-Santini \& Ledoyer, 1974; A. tuberculatum Andres, 1989; A. walkeri (Chilton, 1912).

\section{Diagnostic characters}

A1 with nasiform process on art. 1. Flag. acc. minute to absent. Palp of Md usually with 3 arts., third art. sometimes reduced. Mx1 palp with 2 arts. Mxp IP well separated. Gn1, 2 subchelate, scarcely different in size and shape. Gn1 palm scarcely oblique, palm shorter or equal posterior margin. Gn2 propodus subrectangular, longer than wide, palmar corner nearly rectangular. P5-7 basis rectolinear. Peraeonite 4 much wider than segments 3 or 5 (Barnard \& Karaman 1991: 688 state that peraeonites 4-6 are coalesced, but this is never the case). Body dorsally smooth or with protuberances. Telson huge, vertically inserted, laterally compressed, fleshy.

\section{Antatelson walkeri (Chilton, 1912)}

Fig. 7

Thaumatelson walkeri Chilton, 1912: 199-200 pl. 1, figs 11-15; Schellenberg 1931: 113; Thurston 1974: 24-25

Antatelson J.L. Barnard, 1972: 312

Antatelson walkeri Krapp-Schickel, 2006: fig. 4a, b

? Thaumatelson cultricauda K.H. Barnard, 1932: 113, fig. 62

\section{Material examined}

Two specimens $2.5 \mathrm{~mm}$. RRS James Clark Ross, cruise JR144 (BIOPEARL I), stn JR 144 SR-EBS-4-E, Shag Rocks, 5362'S 4091'W, 11-04-2006, 201-205 m, gear: epibenthic sledge, 4 Epi-net.

\section{Remarks}

Comparing the material here with the illustrations of $A$. walkeri and A. cultricauda (both described as having $3 \mathrm{~mm}$ length) there does not seem any reason for accepting two different species. Gn2 of $A$. walkeri in Krapp-Schickel (2006 fig. 4) is also less widened than in the original description by Chilton, which would be one of the differentiating characters. In A. claudei sp. nov. (see below) there are similar 'pleats' near the dorsal humps as described for $A$. cultricauda and it may well be that in some specimens these are more visible than in others. The mandibular palp has three clearly visibile articles and also in other mouthparts there is no difference with the illustrations for A. tuberculatum by Andres (1989: 183 figs 4-8, 184 figs 12-14).

\section{Antatelson claudei sp. nov.}

Figs 8-9

\section{Holotype}

1 ovigerous $92.5 \mathrm{~mm}$; NHMUK 2011. 8034. RRS James Clark Ross, cruise JR144 (BIOPEARL I), stn JR 144 SR-EBS-4-E, Shag Rocks, 5362'S 4091'W, 11-04-2006, 201-205 m, gear: epibenthic sledge, 4 Epi-net, (slide deposited at the Natural History Museum, London).

Additional 5 specimens sex? 2.1-1.2 mm in alcohol, same locality (Natural History Museum, London). 

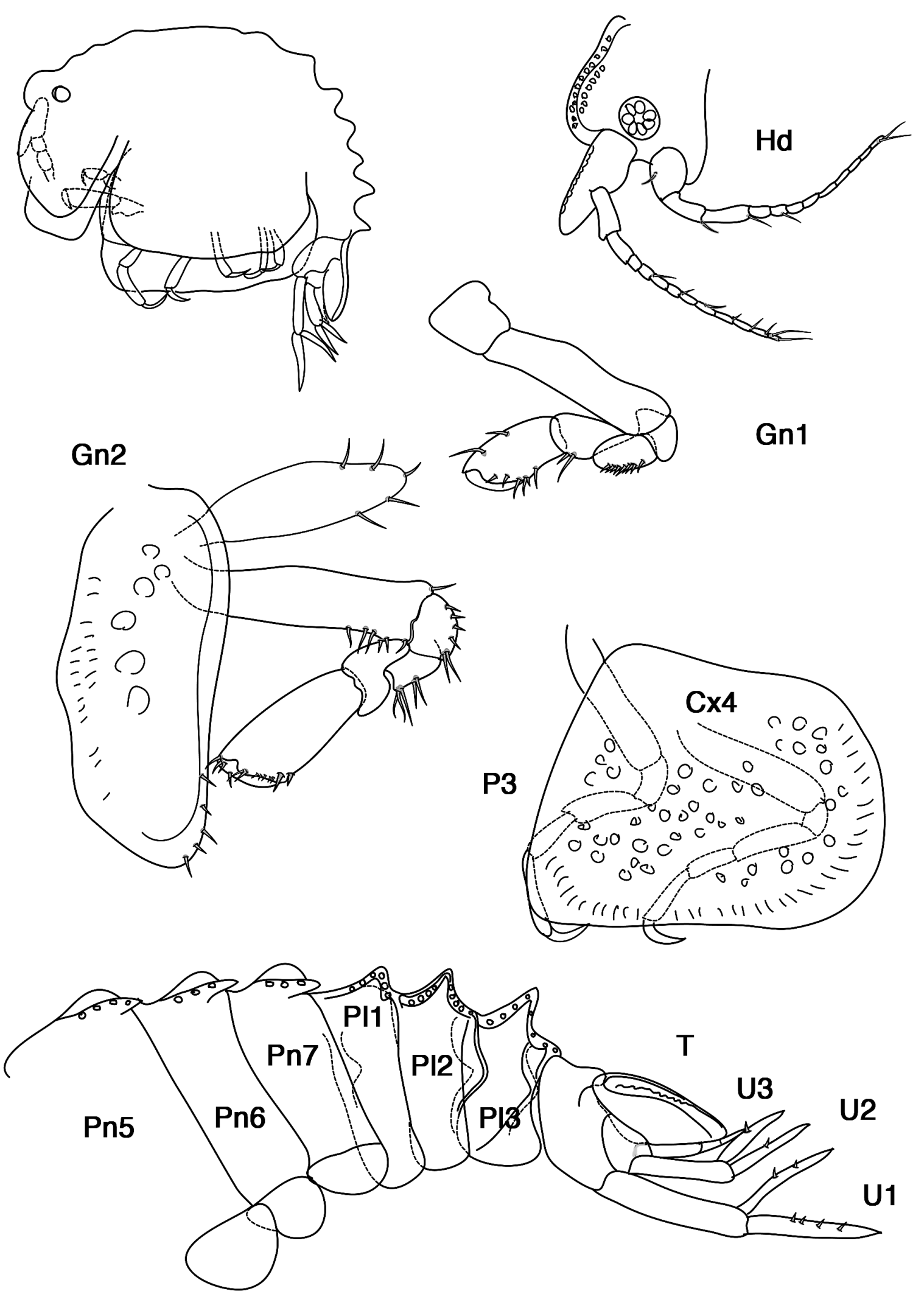

Fig. 8. Antatelson claudei sp. nov. Holotype $q, 2.5 \mathrm{~mm}$. Upper left corner contour of body; $\mathrm{Hd}=$ head; Gn1, $2=$ gnathopod 1, 2; Cx4 = coxa 4; P3, $4=$ peraeopod 3, 4; Pn5-7 = peraeonite 5-7; P11-3 = pleonite $1-3 ; \mathrm{U} 1-3=\operatorname{uropod} 1-3 ; \mathrm{T}=$ telson. 


\section{Etymology}

Dedicated to Claude De Broyer (Brussels) for his strenuous and tireless effort on the studies of Antarctic amphipods.

\section{Description}

HaBITUS. Dorsal outline with single tubercles and humps on the mediodorsal body line, with one at the head, some 3-5 irregular ones on the peraeon, and always acute prolongations on all three urosomites. These dorsal body parts are reinforced with knobs. In dorsal view, the body has a nearly right - angled keel laterally along both sides, thus the cross section would be a rhomboid with a much smaller extent in the upper part than in the lower one.

HEAD. A1 subequal to somewhat shorter A2. A1 ped. art. 1 with huge nasiform process, ratio art. $2>$ art. 3; flagellum with about 10 arts. A2 arts. 2 and 3 short and wide, art. $4=$ art. 5, flagellum with 8-9 arts. Mouthparts: No difference found to those in other species of this genus.

Gnathopods. Gn1 much smaller than Gn2. Cx1 subquadrate. Basis robust, no setae found; ischium subquadrate, naked. Merus beset with short and stiff setae posteriorly; carpus triangular, on posterior margin beset with few longer setae. Propodus about twice as long as wide, on both margins with a few longer setae, palm weakly rounded without well defined palmar corner, but defined by short spines.

Gn2 larger, but also not strong. Cx2 tongue-shaped, longer than wide, anterior margin somewhat rounded, posterior one straight. Basis more than 5 times longer than wide, anterior margin beset with a few fine setae distally, only few setae on posterior margin; ischium longer than wide, with groups of
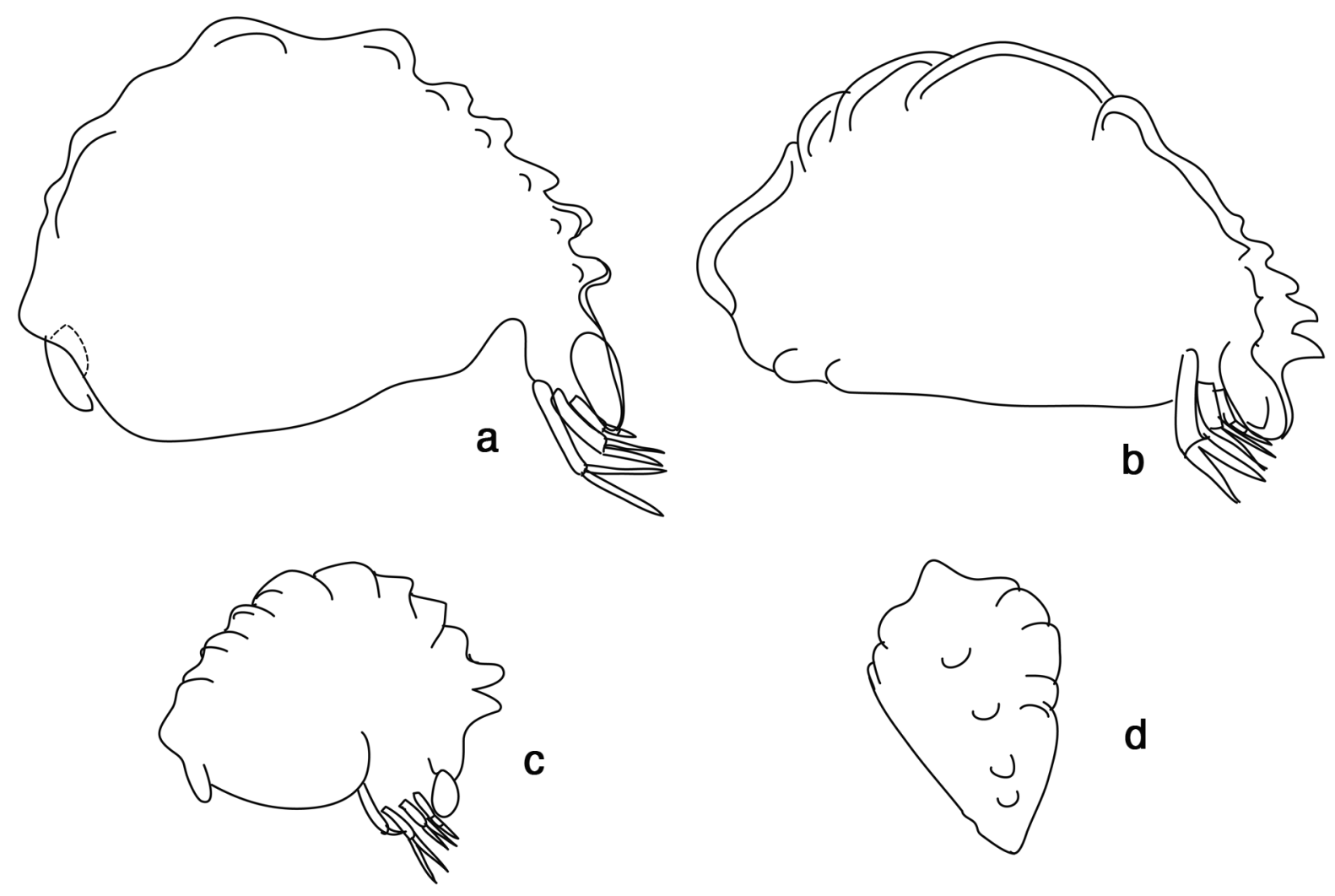

Fig. 9. Antatelson claudei sp. nov. a) Body shape of a $2 \mathrm{~mm}$ long specimen with mediodorsal outline; b) body shape of the same specimen tipped aside to the lateral crest; c) body shape of a $1.2 \mathrm{~mm}$ long specimen with many humps; d) the same specimen seen dorsally. 
setae as on merus. Carpus triangular, about as long as wide, distally lobed, without setae. Propodus subrectangular, distally a bit wider than proximally, with few setae on palmar corner; angle of palmar corner about $120^{\circ}$, without tooth, palm without excavation or incisions, beset with small setae. Dactylus short, reaching palmar corner.

Peraeon. P3-7 slender. Cx3 similar to Cx2. P3 basis about twice as wide as propodus and carpus, merus not lengthened anterodistally. Dactylus strong. P4 similar to P3, but ischium longer in P3. Cx4 subtrapezoidal, clearly wider than long. P5-7 again very similar and weak.

Peraeonites 5-7 with single semicircular dorsal humps situated over an acute tooth-shaped prolongation on each segment, partly reaching over the next segment. In some specimens rounded humps also on 2-3 anterior segments, but without this acute overlapping 'fold'.

PLEON. P11-3 with regular dorsal triangularly thickened prolongations, with 'double pleat', reinforced with knobs.

Ep1-3 with rounded corners.

Urosomites without dorsal ornaments.

Us2 much narrower than Us1.

U1 peduncle longer than subequal rami, rami with small spines. U2 peduncle longer than longer ramus, rami subwhat unequal, with small spines. U3 peduncle shorter than in U2, but similar in width, without spines; ramus two-articulated, about the same length as peduncle.

TeLSON. Enlarged, thickened and vertically inserted.

\section{Remarks}

The first impression was that the material studied belonged to A. tuberculatum Andres, 1989, because, apart from the more numerous humps and tubercles on the body, no difference in the morphology could be found. But in the present material also small specimens of $1.2 \mathrm{~mm}$ length show many more tubercles than the holotype of $2.8 \mathrm{~mm}$ or paratype of $2.6 \mathrm{~mm}$ in Andres' description, thus the idea that the number of humps would increase with body length does not seem justified. And furthermore, Andres stresses in his textual description of A. tuberculatum that the first and second pleon segment carry a pair of tubercles (not visible in the illustrations), and that only the third segment carries a single one. In the specimens of the present study, all segments have a single tubercle in the mediodorsal bodyline.

\section{Amended key to Antatelson species:}

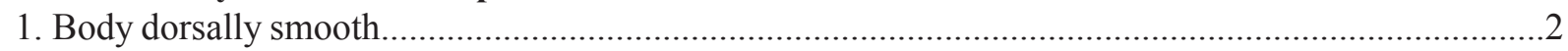

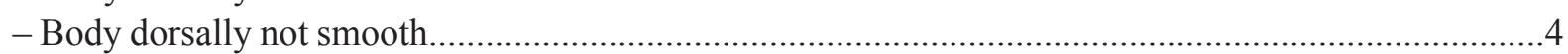

2. Gnathopod 2 carpus elongate, longer than broad............................ cuneatum Krapp-Schickel, 2006

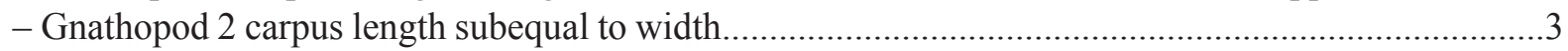

3. Uropod 1 longer ramus much shorter than peduncle; gnathopods with parallel margins.

A. antennatum Bellan-Santini \& Ledoyer, 1973

- Uropod 1 longer ramus subequal to peduncle; gnathopods distally widened

.[Thaumatelson herdmani Walker, 1906]

4. Head with rostrum, body without tubercles or processes, but keeled.

A. rostratum Bellan-Santini \& Ledoyer, 1973

- Head without rostrum, body with tubercles or processes

5. Peraeon and pleon segments with dorsal tubercles.

A. claudei sp. nov.

- Only pleon with tubercles, peraeon smooth..... 
6. Pleon segments 1-3 with tubercles A. tuberculatum Andres, 1989

- Pleon segment 1, 2 smooth, third segment with acute nasiform process, (one upright tubercle), without accompanying small processes. A. walkeri (Chilton, 1912) probably syn. to A. cultricauda (K.H. Barnard, 1932) with accompanying small process.

\section{Acknowledgements}

I am thankful for the possibility to collaborate with the Laboratory of Carcinology, Royal Belgian Institute of Natural Sciences, Brussels, where I always met both interesting and helpful colleagues.

\section{References}

Andres H.G. 1989. Antatelson tuberculatum sp. n., ein neuer Vertreter der Thaumatelsoninae aus der Antarktis (Crustacea: Amphipoda: Gammaridea). Mitteilungen aus dem Hamburgischen zoologischen Museum und Institut 86: 179-184.

Barnard J.L. 1972. Gammaridean Amphipoda of Australia, part I. Smithsonian Contributions to Zoology 103: i-vi + 1-333.

Barnard J.L. \& Karaman G. 1991. The families and genera of Marine Gammaridean Amphipoda (Except Marine Gammaroids). Part 1. Records of the Australian Museum, Supplement 13 (1): 1-417. http://dx.doi.org/10.3853/j.0812-7387.13.1991.91

Barnard J.L. \& Karaman G. 1991. The families and genera of Marine Gammaridean Amphipoda (Except Marine Gammaroids). Part 2. Records of the Australian Museum, Supplement 13 (2): 419-866. http://dx.doi.org/10.3853/j.0812-7387.13.1991.367

Barnard K.H. 1932. Amphipoda. Discovery Reports 5: 1-326.

Bellan-Santini D. \& Ledoyer M. 1974. Gammariens (Crustacea Amphipoda) des Iles Kerguelen et Crozet. Tethys 5 (4): 635-708.

Bushueva I.V. 1988. Two new species of Antarctic scuds of the family Stenothoidae (Amphipoda, Gammaridea). Zoologicheskii Zhurnal 67 (4): 511-517.

Chilton C. 1912. The Amphipoda of the Scottish National Antarctic Expedition. The Transaction of the Royal Society of Edinburgh XLVIII; II 23: 455-520, 2 pls.

Coleman O. 2003. 'Digital inking': how to make perfect line drawings on computers. ODE 3 (4): 303-4. http://dx.doi.org/10.1078/1439-6092-00081

Coleman O. 2009. Drawing setae the digital way. Zoosystematics and Evolution 85 (2): 305-310. http://dx.doi.org/doi:10.1002/zoos.200900008

d'Udekem d'Acoz C. 2010. Contribution to the knowledge of European Liljeborgiidae (Crustacea, Amphipoda), with considerations on the family and its affinities. Bulletin de l'Institut Royal des Sciences naturelles de Belgique, Biologie 80: 127-259.

De Broyer C., Lowry J.K., Jazdzewski K. \& Robert H. 2007. Census of Antarctic Marine Life. Synopsis of the Amphipoda of the Southern Ocean. Vol. 1, part 1: Catalogue of the Gammaridean and Corohpiidean Amphipoda (Crustacea) of the Southern Ocean with distribution and ecological data. Bulletin de l'Institut Royal des Sciences naturelles de Belgique, Biologie 77 Suppl. 1: 1-324.

Krapp-Schickel T. 2006. Thaumatelsonine Stenothoids (Crustacea: Amphipoda) Part 2. Zootaxa 1165: 1-31, 10 figs. 
Krapp-Schickel T. \& Koenemann S. 2006. Cladistic analysis of the family Stenothoidae. Contributions to Zoology 75 (3/4): 169-188.

Krapp-Schickel T. 2009. Stenothoidae. In: Lowry J. K. \& Myers A.A. (eds.): Benthic Amphipoda (Crustacea: Peracarida) of the Great Barrier Reef, Australia. Zootaxa 2260: 872- 879.

Lowry J.K. \& Stoddart H.E. 1995. New Lysianassoid Genera and Species from South-eastern Australia (Crustacea: Amphipoda). Records of the Australian Museum, 47: 7-25.

Schellenberg A. 1926. Die Gammariden der Deutschen Südpolarexpedition 1901-1903. Deutsche Südpolar-Expedition 18 (Zoologie 10): 235- 414, 68 figs.

Schellenberg A. 1931. Gammariden und Caprelliden des Magellangebietes, Südgeorgiens und der Westantarktis. Further Zoological Results of the Swedish Antarctic Expedition 1901-1903 2 (6): 1-290.

Thurston M. 1974. Crustacea Amphipoda from Graham Land and the Scotia Arc, collected by operation Tabarin and the Falkland Islands Dependencies Survey, 1944-59. British Antarctic Survey Scientific Reports 85: 1-89.

Walker A.O. 1906. Preliminary descriptions of new species of Amphipoda from the 'Discovery' Antarctic Expedition, 1902-1904. Annals and Magazine of Natural History Ser. 7 (18): 13-18.

Watling L. 1989. A classification system for crustacean setae based on the homology concept. In: Felgenhauer B.E., Watling L., Thiestle A.B. (eds.) Crustacean issues 6: 15-26. A.A. Balkema, Rotterdam.

Manuscript received: 30 June 2011

Manuscript accepted on: 8 August 2011

Published on: 9 September 2011

Topic editor: Rudy Jocqué

Added on 21-09-2011: In compliance with Article 8.6 of the ICZN, printed versions of all papers are deposited in the libraries of the institutes that are members of the EJT consortium. 